\title{
THE ROLE OF PROPHET MUHAMMAD ON WOMEN EMANCIPATION IN MECCA PERIOD
}

\author{
Shidqy Munjin \\ Universitas Islam Negeri (UIN) Sunan Gunung Djati \\ e-mail:shidqymunjin@gmail.com \\ Ihsan Kamaludin \\ Universitas Islam Negeri (UIN) Syarif Hidayatullah \\ e-mail : ihsankamal95@gmail.com
}

\begin{tabular}{|l|l|l|}
\hline Submission : 4 September 2019 & Revised: 17 December 2019 & Published : 18 December 2019 \\
\hline
\end{tabular}

\begin{abstract}
Islam as one of the religions in the world has several types of social interaction. The way of interaction is called silaturahmi, one of the most pivotal topics in it is communication among Moslem start from Prophet Muhammad spread the Islamic values including in terms of social treatment to others. This article focuses on Prophet Muhammad endeavor for women's emancipation, the struggle begins with the Mecca period until he died. The studying aim is to find out in-depth the prophet Muhammad method and the impact of a social system in there. The method used in this study is descriptive qualitative research expected to be able to reveal qualitative information with description-analysis using the strategy used in this research is a case study. The result indicates the guidance and awareness of women emancipation through the prophet Muhammad strategies pose a huge impact on belief in improving women position in society using the thoughts of feelings and actions in accordance with the teachings of religion in the context of Islam the teachings of revealed Book " the Quran and the Sunnah".
\end{abstract}

Keywords: Gender, Emancipation, Development

\section{Abstrak}

Islam sebagai salah satu agama yang memiliki beberapa tipe interaksi sosial. Cara interaksi tersebut dikenal dengan istilah silaturahmi, salah satu topik paling utama di dalam komunikasi antara muslim dimulai semenjak Nabi Mubammad menyebarkan nilai keislaman termasuk dalam hal perlakuan sosial kepada orang lain. Artikel ini fokus kepada upaya Nabi Mubammad dalam emansipasi perempuan, usaba tersebut dimulai pada periode Mekah bingga ia meninggal. Penelitian ini bertujuan untuk memabami metode Nabi Mubammad dan dampaknya terbadap sistem sosial pada masa tersebut. Metode yang digunakan adalah penelitian kualitatif yang diharapkan mampu untuk mengungkap informasi kualitatif dengan analisa deskriptif menggunakan cara studi kasus. Hasil penelitian ini menunjukan babwa bimbingan dan kepedulian terbadap emansipasi perempuan melalui strategi Nabi Mubammad memberikan dampak yang signifikan dalam peningkatan posisi perempuan di dalam masyarakat menggunakan pemikiran dan tindakan yang sesuai dengan ajaran agama Islam yaitu "Al-Quran dan Sunnab".

Kata kunci: Gender, Emansipasi, Pembangunan

\section{Background}

The emancipation used in this paper is the concept of duality that was conceived by Sachiko Murata ${ }^{1}$. Sachiko Murata's idea is a new concept in looking at gender relations. This concept uses a cosmological approach in looking at the existence and equality between men and women. In Murata's view, the concepts of "maleity" and "femininity" are not

${ }^{1}$ Sachiko Murata, The Tao of Islam (New York: State University of New York, 1992), p. 12. at all related to gender. Both are related to gender relations, so that both men and women have these two characteristics. This is in accordance with the duality of God which has maleness (jalal) such as the Great and feminine (jamil) as the Most Merciful, and because of these two attributes God is called the Perfect (kamal). However, because Sachiko Murata's writing is only limited in the conceptual domain, realistic evidence is needed to strengthen the concept. This paper will provide 
historical data in accordance with the concept stated by Murata ${ }^{2}$.

\section{Mecca's People Believe in Women}

The condition of women in Mecca was not much different from the condition of women in the Arabian Peninsula in general. Even though they had a charming face, they were still oppressed and were always in a subordinate position. But some exceptions occur in women who had a noble family or married by respectable men. People who were lucky like that always made their honor a shield from those who intended to humiliate them ${ }^{3}$.

When the bilf al-fudbûl incident as explained in the previous chapter, not a single woman was present at the house of Abdullah ibn Jud'an. Likewise, when fijar war occurs, women are only used as a means of encouragement and were only given the task of reciting poetry. There were no valuable activities conducted by women at that time. They consider women only as decorations that are only used to be enjoyed by their beauty. Then it is not feasible for women to take part in the battle. As for the women who live in the mountains, their activities were only as breastfeeder for the children of the Mecca conglomerate, as was usually done by Halimah al-Sa'diyah and others ${ }^{4}$.

The people of Mecca only consider that the lineage (nasab / nash) only comes from the male line and women didn't have right for anything ${ }^{5}$. The lineage that comes from women is considered by them as a broken line

2 Sachiko Murata, The Tao of Islam (Bandung: Mizan, 2004), p. 79-113.

3 Ali Jawwad, Al-Mufashshal fì Târikh al-'Arab Qabl al-Islâm (Cairo: Dar al-Saqi, 2001), p. 56.

${ }^{4}$ Muhammad Ibn Sa'd, Thabaqât al-Kubrâ (Beirut: Dar al-Kutub al-'Ilmiyyah), p. 87.

5 Miftahuddin, 'Islam dan Muhammad dalam Perspektif Historis' (Yogyakarta: Faculty of Social and Economy, Yogyakarta State University, 2008), p. 3. or as a cause for shame ${ }^{6}$. They assume that someone who does not have a son is barren, despite having many daughters. Like when the Prophet Muhammad's son, Abdullah, died, Abu Lahab felt very happy and called the Prophet as abtar (barren) ${ }^{7}$.

Strangely, they had the view that it is an honor to be able to marry or marry his son to an honorable woman or woman of respectable descent. Like Abu Lahab who was very happy when he able to marry his two children named 'Utbah and 'Utaibah with the two daughters of the Prophet named Ruqayyah and Umm Kulthum. Even when the Prophet Muhammad had become an enemy of the people of Mecca, Abu Sufyan continued to feel proud when he learned that his daughter was married to the Prophet Muhammad ${ }^{8}$.

\section{Gender Equality in Islam}

Gender equality in the world community still raises the pros and cons, this is due to differences in the concepts held by the community about the roles of men and women. Substantially, Islam does not recognize discrimination between men and women. Basically, Islam places women as equal partners as men. Even if there are differences, then it is due to the main functions and tasks that religion imposes on each sex, so that the differences do not result in one feeling superior to the other. ${ }^{9}$ Both complement and help each other in playing out their functions in life. Islam proclaims the equality of men and women and the integration between the two in

${ }^{6}$ Adele K. Ferdows, 'Women and the Islamic Revolution', International Journal of Middle East Studies, 15.2 (1983), p. 87.

7 Al-Thabari, Târikh al-Umam wa al-Mulûk, 5th edn (Cairo: Dar al-Ma'arif), p. 657. In this book is informed to that who accuse prophet as barren is al'Ash ibn Wail, 'Uqbah ibn Mu'ith, and many more.

8 Ibrahim Al-Jumal, Zaujât al-Nabiy Muhammad, 2nd edn (Cairo: Maktabah Wahbah), p. 87.

9 Zainul Muhibbin, 'Wanita dalam Islam', Jurnal Sosial Humaniora, 4.2 (2011), 109-20. 
acting out their respective functions. ${ }^{10}$ This can be seen in the expression of the Koran which directly aligns the position of men and women, including those contained in QS al-Nisa ': 1, 6, 31, 74, and 97 .

In Islam, the roles of men and women are often divided into public roles (for men) and domestic roles (for women) ${ }^{11}$. The division of roles is often based on Islamic teachings not islamic values itself.

One of the verses that are often debated by several parties, namely Koran chapter AnNisa verse 34 which states that men are leaders for women. This is often the basis that women have an inferior role compared to men. However, Rahmawati mentioned that another verse (Al-Baqoroh verse 282) emphasized that the term Rijal refers to a man who has certain criteria to be a leader.

Some Muslim scholars interpret sex differently from gender, this is done to be able to provide biological and cultural boundaries as stated Mansour Faqih. He argues that gender is an inherent trait of men and women socially and culturally construct ${ }^{12}$. This is based on the use of different languages in the Koran in discussing specific sexes and roles ${ }^{13}$. For example, that woman is feminine, beautiful, emotional, and so on. While men are considered strong, rational, male, mighty, and should not cry.

Characteristics themselves are interchangeable qualities. Changes in these characteristics and traits can occur from time

${ }^{10}$ Heri Junaidi and Abdul Hadi, 'Gender dan Feminisme dalam Islam’, Muwazah, 2.2 (2010), 245-56.

11 Zaky Ismail, 'Perempuan dan Politik pada Masa Awal Islam (Studi Tentang Peran Sosial dan Politik Perempuan pada Masa Rasulullah)', Review Politik, 6.1 (2016), 140-59; Atika Z Sufiyana, 'Relasi Gender dalam Kajian Islam "The Tao of Islam, Karya Sachiko Murata"”, Tadrib, 3.1 (2017), 121.

12 Mansour Faqih, Analisis Gender dan Transformasi Sosial (Yogyakarta: Pustaka Pelajar, 2007), p. 12; Citra Mustikawati, 'Pemahaman Emansipasi Wanita', Kajian Komunikasi, 3.1 (2015), 65-70.

${ }^{13}$ Rahmawati Hunawa, 'Kedudukan Suami-Istri (Kajian Surah an- Nisa' [4]: 34)', Potret, 22.1 (2018), 34. to time and from place to place, also changes can occur from social class to different classes of society. All things that can be exchanged between the nature of women and men can be changed, both time and class. ${ }^{14}$

Another notion was put forward by Nasarudin Umar who stated that gender was a cultural concept that was used to identify differences in roles, behaviors, etc., between men and women who developed in a society based on social engineering ${ }^{15}$. So gender is formed by society and not related to certain physical characteristics.

From the notion of gender according to these experts, it can be concluded that gender is a set of attitudes, roles, responsibilities, functions, rights, and behaviors inherent in men and women due to the formation of culture or the environment of the society in which humans grow and are raised. This means that differences in nature, attitudes, and behaviors that are considered typical of women or typical of men or more popular with the terms femininity and masculinity are mainly the result of one's learning through a long process of socialization in the community, where he grows and grew up. This is different from gender which is distinguished by differences in biological physical features. ${ }^{16}$

Although there are differences in understanding between gender and sex, Muslim communities themselves often mix these two aspects and ultimately eliminate some of the rights held by a party. A Critic from the community for women who work late into the night is one example that is often experienced by women because sometimes it is considered as incorrect women. In the end, many women limit their working hours and activities because they are limited by social assessment.

\footnotetext{
${ }^{14}$ Murata.

15 Nasarudin Umar, Argumen Kesetaraan Gender Perspektif al-Qur'an (Jakarta: Paramadina, 2001), p. 12. ${ }_{16}$ Murata.
} 
Differences in the concept of gender among Muslims are also influenced by differences in the teachings of Fiqh (interpretation and application of Islamic law) taught by four famous scholars namely Maliki, Hambali, Syafii, and Hanafi. The four figures have several legal views related to the position, rights, and obligations of women both in society and in the public sphere.

According to Fatima Umar Nasif, women's rights are divided into four parts, namely: social rights, religious rights, political and military rights, and economic rights. In this study, the emancipation of women to be appointed is related to these four aspects. What is meant by social rights are rights relating to life in general, such as marriage, family treatment, care, inheritance, and so forth. Religious rights are women's rights to carry out aspects of their belief freely without any discrimination from any party. Political rights are related to policies carried out by women that have an influence on the political situation at that time. So politics here also includes deliberation rights, the military, and so forth. The economic right is the right to own and carry out other economic emancipations independently without any intervention from other parties.

One of the well-known females who have written in Koran is Maryam's story that is Jesus (prophet Isa). That new breakthrough made by the Koran is further strengthened by the decline of the Maryam chapter. This chapter is a letter that talks about Mary, a holy woman who gave birth to Jesus. Naming this letter with the name of a woman is certainly a declaration of the Koran regarding the appointment of women. Even in this letter, it is indirectly mentioned that Mary is a woman who outperformed many men. This principle continued to be carried out by Islam until it gave birth to many among Muslim women who had a more active role than men.
The next famous female in Koran after Mary is followed by the descent of the Saba chapter which explains about a queen of Yemen nationality named Balqis who managed to lead his country into a very prosperous country. Even his prosperity is praised directly by the Koran (baldatun thayyibatun wa rabbun ghafür). This letter shows that the Arab Nation was originally a nation that respected women and at the same time dispelled the myths of the Mecca community that considered a woman to be goods which had no sense, had no property rights, and could be traded.

Although there is some debate about the emancipation of women in Islam, history records that it Islam began to include various Qur'anic verses about women. ${ }^{17}$ Also, teaching that women must be considered for their living conditions since prophet taught that mother must be moslem priority.

\section{Prophet Muhammad Strategy to Deal with Women Emancipation}

When the Prophet Muhammad came with Islamic teachings, the condition of women had begun to improve. Muhammad taught a tribute to women that had never been done before (rely on Koran) ${ }^{19}$. So for the first time the Prophet Muhammad preached Islam, there were the names of women who joined the faith in him, such as Khadija bint Khuwailid, then Umm Salamah, Aminah bint Khalaf, Fatima bint al-Mujallil, Fukaihah bint Yasar, Umm Aiman, Sumayyah, and others. Not all of the women above are women of Quraysh or who have noble traditions. Among the Quraysh to there were different degrees of glory. Even Sumayyah and Umm Aiman were not Quraysh but were slaves of Habasyah. But in Islam they are all recognized as al-sâbiqûn alawwalun (the people who first converted to

${ }^{17}$ Kadar M Yusuf, 'Model Emansipasi Qurani terhadap Kaum Perempuan', Al-Fikra: Jurnal Ilmiah Keislaman, 11 (2012), 100.

18 Yusuf.

19 Aslma Barlas, Believing Women in Islam (Texas: University of Texas Press, 2019), p. 12. 
Islam) from among women, a degree of respect that surpasses men who converted to Islam afterward ${ }^{20}$.

On the day that the Prophet Muhammad had shown his form of protest against the public's view at that time regarding women. Abu Qatadah al-Ansari said that the Messenger of Allah had prayed while holding Umamah bint Zainab bint Muhammad. According to the statement of Abul 'Ash bin Rabi'ah bin Abdi Shams, if the Prophet fell down, he laid down Umamah, and if he stood, he held her ${ }^{21}$.

Al-Fakihani commented that the secret of the Prophet's behavior was to insinuate the customs and traditions of Arabs who did not like girls and did not want to carry them. Likewise, when the Prophet Muhammad called on the Quraysh and preached them, the Prophet did not distinguish between men and women. He called Bani Qushay, Bani 'Adi, Bani'Abdu Manaf, Shafiyyah bint 'Abd alMuttalib, Fatima bint Muhammad, Bani Hasyim, and all those who were at that time ${ }^{22}$.

The Prophet also did not discriminate against his opposition to the opposition of men and women. When Abu Lahab opposed the Prophet, his wife also supported her husband in the opposition. So the Prophet recited al-Lahab chapter which contained a curse for the married couple. ${ }^{23}$ As the Prophet also does not distinguish between men and women when giving praise. Like when the Prophet praised Uthman and Ruqayyah, or when he prayed for Yasir and Sumayyah.

The Quraysh made women as a tool to resist the preaching movement of the Prophet Muhammad. Women are only used as a tool to

${ }^{20}$ Ibn Hazm, Jawâmi' Sîrah Nabawiyyah (Beirut: Dar al-Kutub), p. 38.

${ }^{21}$ Bukhari, Al-Jâmi' al-Shabîh, 6th edn, (Cairo: Maktabah Wahbah, t.t), p. 109; Muslim, Al-Jâmi' alShahîh, 1st edn, (Cairo: Maktabah Wahbah, t.t), p. 73.

22 Bukhari.

${ }^{23}$ Read al-Lahab chapter in Koran. protect the interests of men. Like when Mush'ab ibn 'Umair converted to Islam, they encouraged Mush'ab's mother not to eat and drink until Mush'ab would leave the Prophet Muhammad and his teachings. Likewise, when a slave-like Khabab ibn al-Arat converted to Islam, the Quraysh pressed Anmar bint Siba 'al-Khuzza'iyah who at that time was the owner, to torture the Khabbab with a hot iron $^{24}$.

In the first Mecca period (before went to Medina), verses of the Koran that came down to the Prophet revolved a lot in the matter of aqidab (faith) ${ }^{25}$. The way the Koran explains aqidab in this period emphasizes much on the human aspect and not gender. The Koran always mentions khithâb (audience) as humans or by mentioning men and women together. As in chapter of al-Taubah: 72-73, Noah: 28, al-Ahzab 35, 36, 58, 73, and al-Fath: 25. This is an implicit message conveyed by the Koran regarding equality between men and women.

So that the words of the Prophet broke out that stated that women are below men. He always looks at people as same as others and treated them like his family as well.

\section{The Impact of Prophet Muhammad Strategy to Mecca People}

Women's emancipation can also be interpreted as an attempt to demand equality of women's rights in all areas of life ${ }^{26}$. The emancipation of women aims at giving women the opportunity to work, study and work as well as men, in balance with their abilities ${ }^{27}$. The same understanding here is more perceived in parallel terms because it is undeniable that women and men are clearly

${ }^{24}$ Ibn Hisyam, Sîrah Ibn Hisyâm (Cairo: Musthafa al-Bab al-Halbi, 1955), p. 317-21.

25 Amina Wadud, Inside The Gender of Jihad (Oxford: Oneworld, 2006), p. 1.

${ }^{26}$ Christine Schirrmacher, Islam and Society, ed. by Tunnicliffe. Geoff (Bonn: Verlag für Kultur und Wissenschaft, 2008), p. 90.

27 Achmad Syarifudin, 'Peran Strategis Kaum Perempuan dalam Mewujudkan Masyarakat Religi', $A n$ Nisa'a, 12.1 (2017), 31. 
different ${ }^{28}$. Fatima Umar Nasif divided women's rights into four parts, namely: 1) social rights, 2) religious rights, 3) political rights, and 4) economic rights ${ }^{29}$. In this paper, the emancipation of women is focused on those aspects.

\section{Social}

The social situation of women in the Mecca period was not much different from the conditions of other Arab women, both before and after Islam came. This mainly because the presence of Islam which is still new, was not preached frontally. Islam was delivered by the Prophet Muhammad in stages.

The followers of the Prophet Muhammad in Mecca, although united with the same brotherhood and purpose, they still lived in different regions. This different residence made them unable to have any strength when one of them experiences oppression and discrimination. Such conditions lead them unable to perform public worship. Then such a situation narrows the Prophet in creating a new society ${ }^{30}$.

In the former Mecca period, Islam only talks about aqidah and doesn't talk much about the practical norms (muammalab). Even if there was a problem of 'worship, it only revolves around personal worship. So the topic relating to marriages, inheritance, and education was not emphasized in this period. In addition, the condition of the Muslim community at that time did not yet have any strength or power to carry out various teachings policies. Even so, there were some things worth about the activities of Muslim women in the Mecca period which were quite different from other women's activities at that time.

28 Asghar Ali Engineer, Pembebasan Perempuan (Yogyakarta: LKIS, 2003), p. 24.

${ }^{29}$ Fatima Umar Nasif, Menggugat Sejarah Perempuan (Jakarta: Cendikia Sentra Muslim, 2001), p. 65.

30 Shafiyyurahman Al-Mubarakfuri, Rahîq AlMakhtûm (Cairo: Dar al-Wafa, 2005), p. 169.
In the educational sector, for instance, Allah had revealed the Iqra (read) as the first revelation to the Prophet Muhammad. It has a very broad interpretation in terms of philosophical meaning, especially when connected with the world of education. The demand to read the al-Alaq chapter is not only to read what is written but also contains demands to read something that is not written in the universe, such as the phenomenon of weather changes, the change of day and night, and natural events that must be read and studied carefully. The problem of Iqra was not specific to the men only, because the Messenger of Allah was sent to all mankind, including women. Therefore, the concept contained in Iqra as a basis for education does not provide a certain age or gender perspective but covers universality across various boundaries so that the concept of Iqra also applies to women.

Based on that thought, the Prophet made a new breakthrough which was enough to shake the stability of the Quraysh people. On the one hand, The Quraysh, especially their dignitaries, used to hold deliberations or gatherings at Dar al-Nadwah but the participant should be men and women were not allowed to attend the discussion. Even women as smart as Hindun bint 'Utbah have never been permitted to enter this association, even though her husband is a Quraysh leader. On the other hand, the Prophet did the same gathering with his students in a place called Dar al-Arqam. According to Ramadan al-Buthi, Dar al-Arqam was chosen by the Prophet as the headquarters of the movement because of its position close to the Kaaba. The selection of this position seems to contain a message of resistance to the institution of al-nadwah whose positions are also not far from the $\mathrm{Kaaba}^{31}$. In this association, there were not only men, but women like Fatima bint al-

31 Sa'id Ramadhan Al-Buthi, Fiqh al-Sîrah (Damascus: Dar al-Fikr, 2008), p. 69. 
Khaththab, the sister of Umar ibn alKhaththab also followed her. In it, the Prophet taught the basics of Islam and read the revelations he received ${ }^{32}$.

On the marital aspect, the Prophet only conducted monogamy with Khadija bint Khuwailid. His marriage to Khadija was done before Muhammad was made a prophet. Khadija was the only wife of the Prophet who had never been polygamy until dead ${ }^{33}$. The practice of monogamy was also carried out by all followers of the Prophet Muhammad. All those who followed the Prophet during this period did not record polygamy. Like Abu Bakr who did monogamy with Umm Rumman, mother Asma and Aisha. Likewise Ja'far with Asma bint Umais, Uthman ibn Affan with Ruqayyah bint Muhammad, Sa'd ibn Zaid with Fatima bint al-Khaththab, Abu Salamah ibn 'Abd al-Asad with Umm Salamah, Khalid ibn Sa'id with Aminah Binti Khalaf, Hathib ibn al-Harith al-Jumahi with Fatima bint al-Mujallil, al-Khaththab ibn al-Harith with Fukaihah bint Yasir, Muththalib ibn Azhar al-Zuhri with Ramalah Binti Abu 'Auf, and also others ${ }^{34}$. This form of monogamous marriage is quite strange compared to the prevailing marriage practices at that time, which generally carried out polygamy, whether through a legal marriage or not.

Women have been considered as valuable partners. This was exemplified by the Prophet himself when he married Khadija with the dowry of 20 camels. In this marriage, the woman first asked the man to marry her. The process of marriage like this has never been done by the people of Mecca before. ${ }^{35}$

Khadija was the first person to declare faith in Muhammad's apostolate, a millionaire who was willing to sacrifice his property for

${ }^{32}$ Hisyam.

33 Al-Mas'udi.

${ }^{34}$ Hisyam.

35 To look at deeply information about prophet and Khadija can be seen in Hisyam. ; Hajar. ; and alJauzi. the propagation of Islam, a wife who was faithful in joy and sorrow and fully supported her husband's struggle ${ }^{36}$. As is known that Khadija is the main advisor of the Prophet who always provides advocacy whenever the Prophet faces a critical situation. Because of this, Khadija was considered the patron of the Prophet. Through his lobbying ability, the efforts of the Mecca elite to hinder the Prophet's preaching struggle in the city can always be thwarted.

In addition, history also records that Khadija had contributed greatly to building the Prophet's preaching ${ }^{37}$. Like when the Prophet first received revelation in the Cave of Hira, the Prophet felt something he did not normally feel. He immediately returned home with mixed feelings. When he arrived home, Khadija who faithfully welcomed him tried to calm his feelings with her reassuring words. Hearing Khadija's words, the Prophet's heart immediately calmed down. As a wife, Khadija has taken a smart attitude, which is to provide total support for her husband's preaching. Khadija not only became solace when suffering but she also supported the Prophet's preaching with all her energy, wealth, and mind. ${ }^{38}$

Likewise with the lineage of women that in this phase have begun to be recognized as legitimate bloodlines. When the Quraysh only recognized descendants based on the line from men, the Prophet attributed sons sometimes to his mother, not to his father. That was done by the Prophet and his companions. In a narration, it is stated that the Prophet did not bind (the body) Suhail ibn alBaidha (his mother's name) except in the mosque. Ibn Mas'ud was also famous among

36 Yusuf Sidani, 'Women, Work, and Islam in Arab Societies', Women in Management Review, 20.7 (2005), 499.

${ }^{37}$ Ibn Ishaq Al-Muththallibi, Kitâb Al-Siyar Wa Al-Maghâzî (Beirut: Dar al-Fikr, 1975), p. 81.

38 To look at deeply information about this, can be seen in Bukhari. ; , Muslim. 
friends as Ibn Ummi Abd (his mother's name). The Prophet also had a blind muadzdrin known as Abdullah ibn Umm Maktum (his mother's name). This is an inspiration from the Koran which often mentions the name alMasîh as Isa ibn Maryam. All descendants of the Prophet who still exist today, all are descended from his daughter named Fatima from the results of her marriage to Ali ibn Abu Talib.

\section{Religion}

The religious conditions of Mecca women were still in a backward condition as was the prevalence of Arab women at that time. This condition of religious backwardness, as explained in the previous chapter, makes the position of women not as religious subjects, but as objects. There are so many of them who used to make girls who are still virgins as sacrifices for their activities. But surprisingly, they do this because of the direction of the shamans and astronomers who are mostly women.

After Muhammad came with his Islamic da'wah, the religious conditions of women began to be lifted. There are so many verses that explain the equality of rights and obligations between women and men ${ }^{39}$. This can be seen in the message contained in the Maryam chapter verses 16 to 35 which explains the religious status of Maryam bint 'Imran. In it explained the religious position of Mary which is aligned with men who have been appointed as a prophet, such as Zachariah, Yahya, and even Abraham. Those Koran verses give the message that Islam does not distinguish between worship performed by men or women. Even Mary is described as a woman who is more than men. Ibn Hazm in al-Fashl explained that Mary was a prophet from among women. He concluded that

39 Jane I Smith, 'Women in the Afterlife: The Islamic View as Seen from Qur'ān and Tradition', The American Academy of Religion, 43.1 (1975), 40. because Mary was recorded equal to the prophets $^{40}$.

In another Koran's chapter explained in detail the process of the birth of Mary. Actually, Mary's mother was a woman who was looking forward to the birth of a boy she would make as a servant of al-Quds. But when she knew that what she was born was a woman, she asked God that she would someday be what she hoped for even though she was a woman. So when Mary grew up, she became a religionist. It is from this spirit that many of the Muslim women aspire like Mary. Even so, during this period of Mecca women were not yet permitted to carry out religious activities in the public sphere, because it was feared that they would get interference from the people of Mecca. So the limitations of religious activities of women in Mecca, mostly because of conditional pressure and not theological issues. So with the reason, it is appropriate to mention that the Koran implies which the religious status of women, as well as their social status, is the same as men.

\section{Political}

Islam recognizes the importance of women in people's lives and their influence on political life. Therefore women have been given political rights that reflect their dignified, respectful and noble status in Islam. Among the political rights of women were taught by Islam are the right to speak, act and issue opinions.

The Mecca period can be called a political moment for women. In a number of narrations, it was discovered that the political role of women was crucial for the success of the Prophet's mission to Medina. The political role played by Muslim women in Mecca illustrates a precious sacrifice of women for

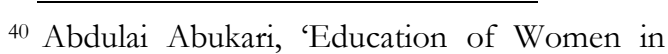
Islam: A Critical Islamic Interpretation of the Quran', Religious Education, 109.1 (2013), 12. 
Islam. Many of them had to lose all their wealth, family and even lives.

At the beginning of Islam was preached by the Prophet in secret and was more personal, one of the former Abu Jahl's slave women claimed to be a follower of Muhammad after listening to the presentation of his son who had previously become a follower of Muhammad. She converted to Islam with her husband. The woman's name is Sumayyah bint Khabath, the mother of Ammar ibn Yasir. 41 She is the seventh and first-person among women who dare to show her Islam before the people of Mecca ${ }^{42}$.

The political game played by Sumayyah was extremely important that largely determined the success of the Prophet's mission. When Abu Jahal knew that his slave was following the teachings of the Prophet, he immediately tortured her in the midst of the Mecca community. Everyone at that time could see the scene of Abu Jahal's torture of Sumayyah and her family.

When Abu Jahal ordered Sumayyah to insult Muhammad, and even he dared to accuse Sumayyah because Muhammad's appearance, Sumayyah immediately spat on Abu Jahal right on his face. Because of this attitude, Abu Jahal immediately thrust a hot iron into Sumayyah's pubic hole until she died. Sumayyah was recorded as the first person to die a martyrdom in Islam. She is a pioneer of martyrs', both for men and women ${ }^{43}$.

After Sumayyah's torture spread out, many female slaves were interested in following the same footsteps. Soon after that event, one of the slaves of the Banu Zuhrah called Ummu 'Ubais converted to Islam and was finally tortured by al-Aswad ibn Abd Yaghuts, a Quraish leader who hated

${ }^{41}$ look at the biography, Al-'Asqalani Ibn Hajar, Al-Ishâbah fî Tamyî̀ al-Shahâbah (Beirut: Dar al-Kutub al'Ilmiyyah, 1994), p. 18.

42 Hajar.

${ }^{43}$ Ibn Sa'd. ; Hisyam.
Muhammad deeply ${ }^{44}$. Then the trail was passed on by a slave girl from Bani 'Adi who was then tortured by Umar ibn al-Khtahthab, who at that time had not yet converted to Islam. Likewise, the same fate suffered by alNahdhiyyah and his daughter.

Torturing continued until the pilgrimage season of the eleventh year of the Prophethood. During this pilgrimage season, the Prophet was visited by residents of Yathrib who claimed to convert to Islam ${ }^{45}$. In the following year, the Prophet was visited again by several people representing their respective tribes and then declared themselves to convert to Islam. This meeting is referred to as the first bai'at 'aqabah. Because of the services of these people Islam began to spread in Yathrib. Then in the thirteenth year of Prophethood, precisely in June 622 AD, the Prophet was visited again by representatives of the population of Yathrib, two of whom were women. They are Nusaibah bint Ka'b from Bani Mazin and Asma Binti Amr from Bani Salamah. Because of the presence of these two women, this meeting was called bai'at al-nis' or known as the second bai'at al aqabah.

Based on the Prophet's agreement with the inhabitants of Yathrib on the Ba'iat al-Nisa that they would guarantee the safety of the Prophet in their village. Then two months and a half of the event, the Prophet told all his followers to emigrate with him to Yathrib. History records that this move to Yathrib was the initial momentum of the glory of Islam. Behind the success of the Prophet's journey to Yathrib was determined by two women, namely:

Asma Binti Abu Bakar al-Siddiq. Aisha told that when the Prophet got permission to migrate to Medina, he came to the house of Abu Bakr. There was no one in the house except Abu Bakr, A'isyah and her brother, Asma Binti Abu Bakar. The Prophet ordered

${ }^{44}$ Hajar.

${ }^{45}$ Hisyam. 
Abu Bakr to release anyone who was in his house. Abu Bakr said that only he and his two daughters were in his house. So he told Abu Bakr that it was permissible for the Prophet to come out of Mecca and emigrate and confirmed that Abu Bakr would accompany him during his journey. No one knows the departure of the Prophet except Ali ibn Abi Talib and Abu Bakr and his family.

Asma bint Abu Bakar al-Siddiq. 'Aisha told that when the Prophet got permission to migrate to Medina, he came to the house of Abu Bakr. There was no one in the house except Abu Bakr and his children. The Prophet ordered Abu Bakr to get out of anyone who was in his house. Abu Bakr said that only he and his two daughters were in his house. So he told Abu Bakr that it was permissible for the Prophet to come out of Mecca and emigrate and confirmed that Abu Bakr would accompany him during his journey. No one knows the departure of the Prophet except Ali ibn Abi Talib, Abu Bakr, and his family ${ }^{46}$.

The role of Asma in this monumental event is very large. She was very secretive of the Prophet. She never spread the whereabouts of the Prophet and her father during the emigration, despite having to receive very harsh treatment. Ibn Ishaq narrated that when Abu Jahl came to the house of Abu Bakr with the leaders of Quraysh, they met Asma and asked where her father was. Asma refused to answer and immediately Abu Jahal slapped her hard so that the earrings came off. Even Asma also kept the departure of the Prophet and her father to her own grandfather who was worried about the condition of Abu Bakr ${ }^{47}$.

Another service that Asma bint Abu Bakr had done was when the Prophet and Abu Bakr hid in the Cave of Tsur. On a dark and lonely night, a woman who was heavily

46 Bukhari, Al-Jâmi' Al-Shahîh.

${ }^{47}$ Hisyam. pregnant was carrying food and taking a fairly steep road for three miles. She climbed a high mountain to reach the Cave of Tsur. For three consecutive nights, Asma delivered supplies for the Prophet and Abu Bakr. Until the third night, because she did not bring anything to tie the food container, Asma stated that there was only a shawl on her waist. Then Abu Bakr told him to split the scarf into two pieces and Asma followed her father's advice. She tied the food in her shawl so that her father could take it. Then the Prophet prayed to Asma, "May Allah replace your scarves with two scarves in heaven." Since then Asma has been dubbed dzât al-nithâqaîn (woman who owns two belts $)^{48}$.

The next person who has been important in the journey of the Prophet Hijrah was Ruqaiqah bint Shaifi. She was a woman who became a spy during a meeting to arrange a strategy of killing the Prophet. In a very gripping meeting, Ruqaiqah managed to absorb all the information available. After the meeting ended, Ruqaiqah reported everything she heard from the meeting. Even Ruqaiqah pointed out several places that would become the Quraysh reconnaissance positions. Besides reporting all that, Ruqaiqah told the Prophet a good strategy for avoiding the siege of the Quraysh and surviving Yathrib. Because of the suggestions from Ruqaiqah, the Prophet finally survived and arrived at Yathrib. Abdullah al-Bajuri asserted that this event was an event that had been removed from the memories of everyone, both Muslims and non-Muslims ${ }^{49}$.

\section{Economy}

Basically, the economic activities carried out by the Mecca's people were just trading activities. This is as explained previously, due

${ }^{48}$ Hisyam.

49 Abdullah Al-Bajuri, Al-Mar'ab al-'Arabiyyah fì Jâbiliyyatihâ wa Islâmihâ (Madinah: Maktabah Tsaqafah), p. 108. 
to natural conditions that are so barren that it made it very difficult for people to plant crops.

Trading activities carried out by Mecca's community began to be standardized since the time of Abd al-Manaf who emphasized his trade trips to Sham and Yemen. When other areas were not suitable to be a trade route because it was always a place of struggle for Rome and Persia. Mecca, which at that time was abstained towards existing politics, became the best alternative route for trading. In addition, Mecca which at that time was the religious center of Arab society further supported this situation.

The background becomes the foundation of Mecca's people's mindset to consider the importance of trade. So whoever controls the trade, he becomes the ruler of his society. Holders of trade control and Mecca's political or economic policies were at that time held by wealthy merchants. This condition made women do not really exist in the economic field. Apart from the trade routes that were impossible for women, Mecca's people highly patriarchal society also did not allow women to have more wealth than men. Women can become a successful merchant if he is indeed from a wealthy family and is married to a wealthy man. This condition was represented by two central women of Mecca at that time, namely, Khadija bint Khuwailid who became a loyal supporter of the Prophet's preaching and Hindun bint Utbah ibn Rabi'ah who in the Mecca period was still a loyal opponent of the Prophet.

Khadija was the daughter of Khuwailid ibn Asad ibn 'Abd al-'Uzza ibn Qushay, a respected descendant of the Quraysh tribe and was among the most respected. Ibn Hisham stated that at that time there were no women who exceeded the glory of Nasab, morality, and none were richer than Khadija ${ }^{50}$. Her father, Khuwailid, was a respected person and was one of those trusted by his trade in Yemen. In fact, he was a trading pioneer with 'Abd al-Muttalib on that path. Khadija was known as al-thâbirab (holy woman) either before or after Islam came, and was considered the leader of the Quraysh woman 51.

Before marrying the Prophet, Khadija had married a superior Quraysh named 'Atiq ibn A'idz al-Makhzumi. After her husband died, Khadija remarried Abu Halah ibn al-Nabasy ibn Zararah al-Tamimi. After her second husband also died, Khadija did not remarry and refused all applications of the Quraysh official who intended to marry her.

During Khadija's widowhood, her activities were focused on the business which she carried on to Sham and Yemen. But in the course of her trade, she represented herself to every man she could trust. Khadija has a mudhârabah system (profit-sharing system) with some of its partners. Until one day word got out that there was a young man who was very trusted in Mecca named Muhammad. So Khadija was interested in doing business with Muhammad and finally gave him confidence in bringing her merchandise to Sham.

Finally, Muhammad departs with Khadija's servant named Maisarah. Certainly, it cannot be imagined that as a businessman, the figure of Khadija is the type of home woman who is not educated. Because if so, how can she run her business well, while she does not have the slightest access to the information behind the walls of her house. From this, it can be understood that even a Prophet's wife had the opportunity to leave the house to take care of her business.

\section{Conclusion}

All of this information shows that the condition of women's activities in the Mecca period treated women badly. However, Islam
${ }^{50}$ Hisyam.
${ }^{51}$ Hajar. 
came and offer some form of emancipation from conceptual ideas.

The idea of emancipation voiced by Islam in this Mecca period can be called the stage of laying the foundation ${ }^{52}$. Considering the condition of women who at that time was really very backward, the idea of Islamic emancipation was a revolution not only for the mentality of the Arabs alone but the whole world in its time. This was compounded by the position of the Quraysh who were the main object of the Prophet who was the mother of all Arab tribes at the time, making the emancipation of Islam even more significant.

\section{References}

\section{Books}

Al-Bajuri, Abdullah, Al-Mar'ah al-'Arabiyyah fî Jâhiliyyatibâ wa Islâmihâ (Madinah: Maktabah Tsaqafah, t.t)

Al-Buthi, Sa’id Ramadhan, Figh al-Sirah (Damascus: Dar al-Fikr, 2008)

Al-Jumal, Ibrahim, Zaujât al-Nabiy Muhammad, 2nd edn (Cairo: Maktabah Wahbah, t.t)

Al-Mas'udi, Murûj al-Dzahab wa Ma'âdin alJaubar (Beirut: Dar al-Ma'rifah, t.t)

Al-Mubarakfuri, Shafiyyurahman, Rahîq alMakbtûm (Cairo: Dar al-Wafa, 2005)

Al-Muththallibi, Ibn Ishaq, Kitâb al-Siyar wa alMaghâż̂̀ (Beirut: Dar al-Fikr, 1975)

Al-Thabari, Târîkh al-Umam wa al-Mulûk, 5th edn (Cairo: Dar al-Ma'arif, t.t)

Ali Engineer, Asghar, Pembebasan Perempuan (Yogyakarta: LKIS, 2003)

Barlas, Aslma, Believing Women in Islam (Texas: University of Texas Press, 2019)

Bukhari, Al-Jâmi' al-Shahîh, 6th edn (Cairo: Maktabah Wahbah, t.t)

Faqih, Mansour, Analisis Gender dan Transformasi Sosial (Yogyakarta: Pustaka

52 Jhon L Esposito, 'Women Right in Islam', Islamic Studies, 14.2 (1975), p. 99.
Pelajar, 2007)

Hajar, Al-'Asqalani Ibn, Al-Ishâbah fî Tamyî̀ alShahâbah (Beirut: Dar al-Kutub al'Ilmiyyah, 1994)

Hazm, Ibn, Jawâmi' Sîrah Nabawiyyah (Beirut: Dar al-Kutub, t.t)

Hisyam, Ibn, Sîrah Ibn Hisyâm (Cairo: Musthafa al-Bab al-Halbi, 1955)

Ibn Sa'd, Muhammad, Thabaqât al-Kubrâ (Beirut: Dar al-Kutub al-'Ilmiyyah, t.t)

Jawwad, Ali, Al-Mufashshal fî Târikh al-'Arab Qabl al-Islâm (Cairo: Dar al-Saqi, 2001)

Miftahuddin, Islam dan Mubammad dalam Perspektif Historis (Yogyakarta: Faculty of Social and Economy, Yogyakarta State University, 2008)

Murata, Sachiko, The Tao of Islam (New York: State University of New York, 1992)

- The Tao of Islam (Bandung: Mizan, 2004)

Muslim, Al-Jâmi' Al-Shahîh, 1st edn (Cairo: Maktabah Wahbah, t.t)

Nasif, Fatima Umar, Menggugat Sejarah Perempuan (Jakarta: Cendikia Sentra Muslim, 2001)

Schirrmacher, Christine, Islam and Society, ed. by Tunnicliffe. Geoff (Bonn: Verlag für Kultur und Wissenschaft, 2008)

Umar, Nasarudin, Argumen Kesetaraan Gender Perspektif al-Qur'an (Jakarta: Paramadina, 2001)

Wadud, Amina, Inside The Gender of Jihad (Oxford: Oneworld, 2006)

\section{Journals}

Abukari, Abdulai, 'Education of Women in Islam: A Critical Islamic Interpretation of the Quran', Religious Education, 109.1 (2013), 12.

Esposito, Jhon L, 'Women Right in Islam', Islamic Studies, 14.2 (1975), 99.

Hunawa, Rahmawati, 'Kedudukan Suami-Istri (Kajian Surah an- Nisa' [4]: 34)', Potret, 22.1 (2018), 1-12. 
Ismail, Zaky, 'Perempuan dan Politik pada Masa Awal Islam (Studi Tentang Peran Sosial dan Politik Perempuan pada Masa Rasulullah)', Review Politik, 06.01 (2016), 140-59

Junaidi, Heri, and Abdul Hadi, 'Gender dan Feminisme dalam Islam', Muwazah, 2.2 (2010), 245-56

K. Ferdows, Adele, 'Women and the Islamic Revolution', International Journal of Middle East Studies, 15.2 (1983), 54

Muhibbin, Zainul, 'Wanita dalam Islam', Jurnal Sosial Humaniora, 4.2 (2011), 109-20

Mustikawati, Citra, 'Pemahaman Emansipasi Wanita', Kajian Komunikasi, 3.1 (2015), 65-70

Sidani, Yusuf, 'Women, Work, and Islam in Arab Societies', Women in Management Review, 20.7 (2005), 499

Smith, Jane I, 'Women in the Afterlife: The Islamic View as Seen from Qur'ān and Tradition', The American Academy of Religion, 43.1 (1975), 40

Sufiyana, Atika Z, 'Relasi Gender dalam Kajian Islam "the Tao of Islam, Karya Sachiko Murata”, Tadrib, 3.1 (2017), 121.

Syarifudin, Achmad, 'Peran Strategis Kaum Perempuan dalam Mewujudkan Masyarakat Religi', An-Nisa'a, 12.1 (2017), 31

Yusuf, Kadar M, 'Model Emansipasi Qurani terhadap Kaum Perempuan', Al-Fikra: Jumal Ilmiah Keislaman, 11 (2012), 100. 